Marijana Jeleč, University of Zadar, Croatia - Iris Spajić, Josip Juraj Strossmayer University of Osijek, Croatia

\title{
Obitelj u krizi i posljedice nemogućnosti svladavanja krize u austrijskom romanu
}

\section{Abstract: Family in Crisis and the Consequences of the Impossibility to Overcome the Crisis in Austrian Novels}

Contemporary Austrian novels with a family theme go beyond the problematization of twogenerational conflicts and tell the story of at least three generations of the family. These are generational novels that often deal with the phenomenon of crisis and the collapse of the family as a result of the crisis. The paper shows that historical caesuras run through the generational novel, showing the causes and consequences of major socio-political changes on the family, which is the basis for all family conflicts in the novel Es geht uns gut (We're Doing Fine) by Austrian writer Arno Geiger. The approach to the topic begins with a conceptual definition of the crisis and the family, and a reflection on their interconnectedness. When it comes to crisis, the starting point is that it requires a reaction within the community, and that the lack of an appropriate response leads to disintegration; in this particular case it concerns the family but can be reflected in the wider society. The aim of this paper is to determine the cause of the family crisis in the novel, to describe how the crisis manifests itself and what the response to it is ${ }^{[1]}$

Keywords: Arno Geiger, family, crisis, family collapse, generational novel, identity

\section{Uvod i pojmovno određenje}

Pojam krize proučava se u brojnim znanstvenim disciplinama i područjima, pa shodno tome postoje i brojna određenja toga pojma. Kriza se u općem smislu može definirati kao „dubok, sveobuhvatan poremećaj u životu pojedinca ili zajednice sa snažnim i više ili manje teškim i trajnim 
posljedicama (Kovačec 506)". U staroj se Grčkoj riječ odnosila na presudu ili odluku, odnosno na „trenutak koji odlučuje o daljnjem pozitivnom ili negativnom razvoju neke stvari ili situacije” (Kešetović i Toth 37). Kešetović i Toth opisuju krizu kao sveprisutnu, kao točku preokreta u razvoju događaja i aktivnosti, ali i kao opasnost za ciljeve i vrijednosti. Osim toga, navode da kriza za razliku od katastrofe daje prostora za odluke, da se na nju može utjecati i da njezin ishod može biti ili dobar ili loš. Ona pogađa veći broj dionika, vremenski je ograničena jer ima početak, razvoj, vrhunac i rasplet te povećava stres i mijenja odnose među dionicima. Također, termin označava raspravu, svađu, prosuđivanje i kušnju, kao i „prolazno teško stanje u svakom prirodnom, društvenom i misaonom procesu" (Filipović 182). S druge strane, hebrejsko značenje riječi kriza znači slomiti, nešto što je slomljeno, ali i rješenje. Ona se odnosi na „egzistencijalni trenutak kad je nešto prekinuto, slomljeno ili uništeno kako bi se oslobodilo mjesto za nešto novo ili drukčije... Tako gledano, može se reći da je kriza 'kritičan', odlučujući trenutak kad se problem na silu rastavlja na sastavne dijelove i rješava" (Dattilio i Freeman 456). Kriza se može odvijati na dvije razine: osobnoj i društvenoj. Osobna razina odnosi se na odstupanje od dotadašnjeg funkcioniranja u smislu izloženosti stresu ili kakvom psihičkom opterećenju i napetosti (Ivanović 12). U filozofiji kriza se može odnositi na unutarnju podijeljenost čovjeka, kao i na čovjekovu težnju da ponovno pronađe vlastitu bit. Kriza se može definirati i kao „[p]rivremeno stanje uznemirenosti i dezorganizacije, koje prvenstveno obilježava nemogućnost pojedinca da izađe na kraj s nekom situacijom primjenom uobičajenih načina rješavanja problema, a koja može imati drastično pozitivan ili negativan ishod" (Dattilio i Freeman 3). Društvena razina usmjerena je na prijeteću pojavu u ekonomskom, kulturnom, političkom i socijalnom smislu (Ivanović 12). Budući da je kriza prisutna u svim aspektima ljudskog života, ona neizbježno utječe i na promjene u obitelji kao temeljnoj društvenoj jedinici. Tradicionalno poimanje obitelji podrazumijeva nuklearnu obitelj koja obuhvaća dvije generacije, odnosno roditelje i djecu. Uz to je usko vezan i pojam proširene obitelji, koji obuhvaća i treću generaciju ili osobe koje pripadaju istoj generaciji kao roditelji. Rinaldi (2006) navodi da je obitelj krhka dinamična struktura osjetljiva na vanjske utjecaje i unutarnje promjene koje proizlaze iz promjena u obiteljskoj strukturi i odnosa članova obitelji (prema Jurčević Lozančić 142). Wagner-Jakab (2008) također govori o obitelji kao dinamičnoj strukturi te navodi da promjene (odrastanje, pubertet, sazrijevanje, klimakterij, starenje), struktura obitelji (dolazak i odlazak članova), različite uloge u različita vremena (dijete, adolescent, roditelj, skrbnik roditelja) i životne 
situacije (bolest, smrt, kriza, nezaposlenost, poslovni uspjeh) utječu na promjene odnosa unutar obitelji. Može se reći da su „u samo nekoliko generacija obitelji ... pod utjecajem šireg društvenog konteksta doživjele velike promjene u svojoj strukturi, ulogama, zadaćama, funkcijama, što se odrazilo na međusobne odnose i sustav obiteljskih vrijednosti (prema Jurčević Lozančić 143).” Obitelj se ne može promatrati kao entitet za sebe jer je sastavljena od pojedinaca koji prolaze kroz različite životne faze, od kojih je svaka usko vezana uz ideju o onome što se od njih očekuje. Ideali o ponašanju žena, muškaraca i djece prisutni su u svakom društvu, a nemogućnost ispunjavanja predodređenih uloga može dovesti do konflikta (Moore 3), a posljedično i do krize obitelji.

Uzevši u obzir važnost obitelji u društvu, ne čudi da je upravo ona često u središtu književnih djela. Generacijski roman jedna je od književnih vrsta koja se bavi upravo tom tematikom. Obitelji koje su prikazane u ovakvim romanima obično pripadaju skupinama koje trenutno prolaze razdoblje raspada ili promjene. Jedno od glavnih obilježja generacijskog romana jest da povijest nekoliko generacija obitelji čini srž radnje, a ponekad je zabilježena u nekoliko svezaka romana. Obiteljske priče dviju, triju ili više generacija odvija se u određenom povijesnom razdoblju, a pripovijedano vrijeme obično se proteže kroz nekoliko desetljeća. Pripovijedano vrijeme i pripovjedno vrijeme obično su u isprekidanom odnosu. Vrijeme u romanu ima ključnu ulogu, budući da je riječ o povijesnom periodu, ali i o biološkom vremenu koje obuhvaća nekoliko generacija, a pripovjedač događaje promatra s vremenskim odmakom (Kiss 165). Suvremeni generacijski romani obično tematiziraju fenomen krize i propadanja, što je vezano uz trenutačni diskurs o obitelj, pa je fokus u takvim romanima stavljen na promjene u odnosima među likovima unutar vremena odvijanja radnje. To je posebno važno jer se u generacijskom romanu ne govori samo o promjenama unutar nuklearne obitelji, već unutar generacija koje žive u različitim vremenima i povijesnim okolnostima. Primjera je takvih romana koji obuhvaćaju višegeneracijske obiteljske sustave mnogo, kao na primjer Ludwigs Zimmer (Ludwigova soba) Aloisa Hotschniga, Haus der Kindheit (Kuća iz djetinjstva) autorice Anne Mitgutsch, Vienna (Vienna) Eve Menasse, Eine sehr kleine Frau ( Majušna žena) Petera Henischa, Die blaue Brosche. Geheimnis einer Familie (Plavi broš. Tajna jedne obitelji) Maxa Kübecka, Es geht uns gut (Dobro nam je) pisca Arna Geigera, od kojih su svi osim romana Arna Geigera prevedeni na hrvatski jezik. Osnovni je cilj ovog istraživanja ispitati 
način na koji je kriza obitelji prikazana u generacijskom romanu Arna Geigera, što uključuje utvrđivanje uzroka krize obitelji u romanu i reakcija na nju.

\section{Es geht uns gut u kontekstu žanra generacijskog romana}

Poznati austrijski pisac Arno Geiger (1968.) književnu slavu stječe 2005. godine objavljivanjem romana Es geht uns gut, kada postaje i dobitnikom prve Njemačke nagrade za književnost. Ovo priznanje potiče veliko zanimanje književne kritike i publike ne samo za Geigerov roman, već općenito za prikaz obitelji i njezine prošlosti u društvenim i političkim okolnostima i s tim u vezi zanimanje za individualno i kolektivno sjećanje na istu. Dakako, nije obitelj te godine prvi put postala predmetom zanimanja književnika s njemačkog govornog područja. Obiteljski sustav i odnosi unutar tog sustava bili su i ranije u njihovu vidokrugu, kada su u austrijskoj književnosti primjerice u tzv. „Väterliteratur” 1970-ih godina prikazivani odnosi između očeva i sinova, u poslijeratnoj njemačkoj književnosti urušavanje obiteljskog sustava zbog gubitka članova obitelji ili propadanje obitelji koje je u svom djelu Buddenbrooks. Verfall einer Familie (Buddenbrookovi. Propadanje jedne obitelji) početkom istog stoljeća prikazao njemački romanopisac i nobelovac Thomas Mann. Premda pripovjedna književnost s naglaskom na prikazu obitelji nije bila nikakva novost i u većoj ili manjoj mjeri bila je prisutna u svim književnim pravcima, u prvom desetljeću 21. stoljeća doživjela je pravi procvat na cijelome njemačkom govornom području, pa i šire. Od tada su romani o obitelji dobivali različite nazive, a u novije vrijeme najviše se istaknuo pokušaj da se razluče pojmovi obiteljskog (njem. „Familienroman”) i generacijskog romana (njem.

„Generationenroman”). Potonji je naposljetku definiran kao svojevrsni podžanr obiteljskog romana. Pritom se u generacijskim romanima zapaža trijadična generacijska struktura, pa se time nadilazi problematiziranje dvogeneracijskih sukoba i prikazuje obitelj kroz nekoliko generacija. Postoje tri konstante kada je riječ o suvremenom generacijskom romanu, a to su njegova povijesna usredotočenost, veća distanca prema prošlosti i širi vremenski okvir u odnosu na obiteljske romane. Valja napomenuti da se generacije jedne obitelji u generacijskim romanima označavaju iz perspektive pripovjedača, počevši od najstarije prikazane kao prve (generacija djedova i baka), pa druge (generacija roditelja) i treće (generacija unuka). 
Već je u uvodu ovoga poglavlja ukazano na činjenicu da siže generacijskog romana Es geht uns gut teče u dvije paralelne fabule: obiteljskoj i povijesnoj, odnosno privatnoj i kolektivnoj. S jedne strane to je pripovijedanje o prošlosti i sudbini građanske bečke obitelji. S druge strane, prikaz sudbine austrijske obitelji neizbježno obuhvaća povijesna i društvena zbivanja u Austriji. Budući da se radnja odvija od 1938. do 2001. godine i tako najvećim dijelom zahvaća 20. stoljeće, prikazuju se i političke, povijesne i društvene prilike toga razdoblja, pa se ovaj roman smatra „romanom o Austriji" (Landerl). Upravo se povijesna usredotočenost ističe kao zajednički nazivnik suvremenih austrijskih generacijskih romana, a njihovi junaci i najmlađi potomci obitelji dijele istu znatiželju i potrebu za rekonstrukcijom podrijetla i za razjašnjavanjem obiteljske prošlosti i svih okolnosti u kojima je obitelj živjela, a sve s namjerom da se sjećanje na prošlost i obitelj održi. Ovi romani tako postaju društvena, politička i kulturno-povijesna svjedočanstva, čime tematski obogaćuju i šire granice te književne vrste, zadržavajući pritom uvijek u fokusu obitelj kao zrcalo društva. Aleida Assmann, njemačka kulturologinja i književna povjesničarka, generacijske romane svrstava u romane sjećanja koji rekonstruiraju „zaboravljene epizode nacionalne povijesti i obrađuju pitanja tumačenja prošlosti u društvu pod političkim pritiskom" (Assmann 51), dok Markus Neuschäfer taj pojam veže uz „tekstove u kojima se 'velika' povijest pripovijeda u vezi s događajima i tijeku 'male' obiteljske povijesti" (Neuschäfer 13).

Postoje, međutim, pojedini romani u suvremenoj austrijskoj književnosti koji predstavljaju otklon od takve tradicije, što se prvenstveno očituje u neželjenom prisjećanju i međugeneracijskom neslaganju, a to obitelj dovodi u stanje krize, pa se ona sa svakom novom generacijom sve više raspada jer nijedna nije u stanju održati obitelj na okupu. Prema takvom kodu nastao je i Geigerov roman, a moglo bi se reći da ovaj roman upravo tako prkosi ustaljenoj formi generacijskog romana nakon 2000. godine. Ipak, roman unatoč tomu što prikazuje neželjeno bavljenje prošlošću otkriva svoj društveno-povijesni kontekst, što je i u ovom austrijskom generacijskom romanu ključ za razotkrivanje onoga što je unutar obitelji, ali i na nacionalnoj razini prešućeno. Takav stav prema prošlosti i generira krizu na više razina.

\section{Simptomi obiteljske krize i reakcije aktera romana}


Radnja u romanu ne teče kronološki. Ona je smještena u Austriji i obuhvaća više od pola stoljeća. Philipp Erlach glavni je lik u romanu, predstavnik treće generacije i njegova je perspektiva relevantna kada je riječ o prikazu kontinuiteta problematičnih odnosa u obitelji. Od svoje bake 2001. nasljeđuje obiteljsku vilu u predgrađu Beča i silom prilika suočava se s prošlošću. Budući da ga prošlost obitelji ne zanima, odmah po preuzimanju obiteljske vile donosi odluku o saniranju i uklanjanju svega što se u tom trenutku u njoj nalazi, uključujući namještaj i osobne stvari članova obitelji koji su nekada u njoj živjeli. Proteklih desetljeća u kući su se nakupile obiteljske fotografije koje svjedoče zajedničkim trenutcima, kao i brojni drugi predmeti koji se vežu uz različite događaje u prošlosti obitelji. U kući su se nakupili i prašina, smeće i golubovi, koji su se ugnijezdili na tavanu vile, kojemu je sam pristup zbog životinja i neugodnih mirisa nemoguć. Za glavnog lika i povijest obitelji nepristupačna je, a Philipp i ne pokazuje posebno zanimanje za nju. Saniranje kuće smješteno je u sadašnjosti i ono predstavlja okvirnu radnju romana. U ukupno osam poglavlja pripovijeda se zatim o događanjima iz prošlosti, o sudbinama njegovih članova obitelji. Richard i Alma predstavljaju prvu generaciju u romanu, odnosno djeda i baku glavnog lika. Tadašnji rukovoditelj pravnih i administrativnih poslova, Richard Sterk, i mlada studentica Alma Arthofer upoznaju se 1929. godine u Beču. Alma prekida svoj studij i u potpunosti se posvećuje obiteljskom životu, prije svega sinu Ottu koji se rađa 1931. i kćeri Ingrid, koja dolazi na svijet pet godina poslije. Richard je ambiciozan i napreduje na mjesto zamjenika direktora gradskih elektrana, dok Alma za to vrijeme skrbi o djeci i kućanstvu. U tome joj pomaže kućna pomoćnica s kojom Richard započinje višemjesečnu aferu. Nakon nekoliko neuspjelih pokušaja da aferu prekine, Richard joj napokon daje otkaz, a prije odlaska iz kuće ona po zidnim tapetama u svojoj sobi ispisuje riječi „Mrzim te”. Alma ne otkriva da zna za suprugovu aferu. U vrijeme obrane Beča od sovjetske Crvene armije Alma i Richard doživljavaju prvu veliku obiteljsku tragediju. Njihov sin Otto umire u dobi od četrnaest godina. Obitelj se počinje sve više raspadati kada Ingrid, koristeći se svakom prilikom da prkosi ocu, odluči udati se za Petera Erlacha. Na zajedničkom izletu sa svojom djecom Ingrid pada u Dunav i utapa se. Richard na kraju obolijeva od demencije i odlazi u dom gdje i umire. Alma umire u zimu 2000. godine i obiteljsku vilu ostavlja unuku Philippu, koji naposljetku briše sve tragove života u njoj i napušta Austriju. 
Na temelju različitih perspektiva u romanu doznaje se više iz života obitelji Sterk-Erlach, obiteljske svakodnevice, o sukobima u obitelji i međugeneracijskim odnosima, različitim gledištima i stavovima, obiteljskim tragedijama, tajnama, uspjehu i neuspjehu, odrastanju i starenju te naposljetku o umiranju svjedoka vremena, dok okvirna radnja pobliže prikazuje sve doživljaje glavnog lika u procesu obnavljanja obiteljske kuće i njegove stavove prema prošlosti. Na taj način nastaje tzv. „multiperspektivna obiteljska povijest” (Kriegleder 229). No ono što Geigerov roman najbolje opisuje i što se može smatrati i bitnim uzrokom krize unutar obitelji jest nedostatak komunikacije, tj. tendencija da se o ključnim događajima iz povijesti obitelji ne govori. Ne samo da se prešućuju uloge muških članova obitelji za vrijeme Drugog svjetskog rata u Austriji, nego i privatne obiteljske tragedije postaju tabu-teme. Naslov romana Dobro nam je stoga nije samo paradoksalan, nego i kontradiktoran. Istina je, naime, ta da nije sve u redu. Kao često korištena tvrdnja u obitelji pokazuje i svoje opasnosti. Njome se samoobmanjuje, negira se realno stanje i ona sprečava svaku daljnju komunikaciju o problemima kako bi se izbjeglo narušavanje reda i mira, no upravo se takav pristup u romanu pokazuje uzrokom krize. $U$ vezi s tim autor ističe:

„Dobro nam je” jedna je od onih floskula koja sprečava nastanak interakcije. ... To su samo izgovori koji služe tomu da se ne mora dati pravi odgovor. I roman tako govori o tome što se iza te floskule skriva. Bitno mi je bilo prikazati sve te detalje koji nastaju iza te fasade. Knjiga prikazuje nemogućnost komuniciranja, koja je opet povezana s osobnim iskustvima, što nije bilo samo u mojoj obitelji očigledno: očevi koji nisu sudjelovali u obiteljskom životu, pitanja o obitelji na koja nije bilo odgovora. (Prangel)

Tom tvrdnjom, odnosno takvim stavom zauvijek je blokiran pristup značajnim pojedinostima iz obiteljske prošlosti i sistematizaciji prošlosti. lako sama obiteljska kuća sadrži mnoga za suvremene austrijske generacijske romane inače tipična opredmećena sjećanja, ona za njega predstavljaju tek stare predmete pune prašine od kojih nema koristi. Bavljenje tim predmetima bilo bi deprimirajuće jer ih on ne može povezati s prošlošću i u tom smislu one ništa ne govore, a pogotovo nemaju emocionalnu vrijednost koja bi eventualno spriječila njihovo uništavanje. Carolina Schutti njegovo postupanje s tim predmetima i saniranje obiteljske kuće ipak tumači kao način obračuna s obitelji, odnosno kao pokušaj oslobađanja od obiteljske zajednice i prešućenih i 
nepovezanih aspekata njezine prošlosti s ciljem uspostavljanja vlastitog identiteta (Schutti 150-51).

Roman, dakle, pored obiteljskog i kolektivnog identiteta propituje i individualni identitet, tj. posljedice koje obiteljska kriza ima po njegovu uspostavljanju. Individualni i obiteljski identiteti po tome su ovisni jedni o drugima, s čime se slažu i Gudehus, Eichenberg i Welzer: „Ako se želi razumjeti pojedinog čovjeka u njegovu individualnom razmišljanju i sjećanju, onda ga se mora povezati s različitim skupinama kojima on istodobno pripada i lokalizirati ga unutar određene skupine." (86). Povezivanje glavnog lika sa skupinom kojoj on pripada baš i stvara situacijske slike koje ukazuju na dubinu raskola, unutar obitelji, potpuno razdvajanje koje glavni lik osjeća s članovima svoje uže obitelji dovode ga i u faze u kojima propituje svoj vlastiti identitet. K tomu distanciranje ili oslobađanje od obiteljske povijesti sa sobom donosi i gubljenje osjećaja pripadnosti obiteljskoj zajednici. To pak olakšava iznošenje brojnih kritika na račun prethodnih generacija i njihova načina ophođenja s prošlošću, premda i on sam nesvjesno nastavlja „obiteljsku tradiciju”. Činjenica je da se glavni lik želi „osloboditi” obitelji i onoga što je od nje mogao naslijediti u materijalnom, ali i u nematerijalnom smislu u potpunosti mijenja polazišta na kojima on gradi svoj osobni identitet. Time roman govori i o životnoj krizi pojedinca, nastavno na krizu obitelji, a koja je moguće i time generirana. Ona je zorno prikazana u trenutku kada Philipp u obiteljskoj kući zapaža fotografiju svoje majke i konstatira da o njoj ne zna gotovo ništa, ali i da više ne vrijedi razmišljati o tome: „Mislim da nema baš nikakva smisla pokušavati tu nešto nadoknaditi. Radije razmišljam o vremenskoj prognozi. ... O vremenu tog dana koje mirišem u Johanninoj kosi, o vremenu sljedećih dana .... O vremenu umjesto o ljubavi, umjesto o zaboravu, umjesto o smrti." (Geiger 10). Premda iz njegovih komentara i zaključaka odmah ne proizlazi da obitelj potpuno zaokuplja njegovu pozornost, pa i kada tvrdi da o njoj više ne želi razmišljati, on to ipak čini, nastojeći pri tome pronaći način, odnosno strategiju koja će osigurati kontrolu nad njegovim emocijama i mislima:

Sve što radiš pokušaj je da zadržiš kontrolu. Tvoja pasivnost strateška je pasivnost koja te treba čuvati od opasnosti izlaganja stvarima koje nisu ugodne. ... Vjeruješ da katastrofe možeš izbjeći ili barem probleme pojednostaviti tako da se što je manje moguće pokrećeš. Tvoja je strategija stajati tri metra od ulice pa i po cijenu da život pored tebe prolazi. Sve je to samo da bi se izbjegla katastrofa. (Geiger 187) 
Odgovorne za nedostupnost informacija traži u vlastitoj obitelji i na prigovore iz njegove neposredne sredine da se premalo bavi svojom obitelji odgovara da nije „njegova krivnja što ga se glede obitelji zaboravilo na vrijeme senzibilizirati” (Geiger 11). K tomu ironično primjećuje da je njegov otac „tijekom prošloga stoljeća zaboravio govoriti” (Geiger 98), što je karakteristično ponašanje generacije roditelja koja se ne želi prisjećati svoje političke opredijeljenosti i vlastite umiješanosti u zbivanja tijekom Drugoga svjetskog rata. Da je obitelj s trećom generacijom utonula u još dublju unutarnju krizu očitije se prikazuje njegovim nalogom za uklanjanjem svih uspomena i drugih predmeta iz kuće, koji su desetljećima ležali u njoj. Naručuje velike kontejnere u koje se baca sve što je njegova baka iza sebe ostavila. lako mu od početka ta odluka nije osobito teško pala, u trenutcima punjenja kontejnera osobnim stvarima članova obitelji pokušava se opravdati i sebe uvjeriti da postupa ispravno:

Nemoj sad samo razmišljati o tome hoće li ti ovaj ili onaj predmet sada ili poslije moći koristiti, ne slušaj Johannine pozive na grižnju savjesti, ignoriraj glas koji ti došaptava i uvjerava te da se može i pretjerati i da onaj koji se ponaša tako, kao ti, zauvijek mora biti izopćen i sam. Imaj u vidu da je samozaštita ispravan refleks i da je tebi prepušteno da odlučiš što ti odgovara, a što ne. Sjeti se da je sjećanje na obitelj konvencija, izmišljena od onih koji ne mogu podnijeti umiranje i padanje u zaborav. Misli na indijanska plemena u kojima najveći ugled ima onaj koji svoju imovinu najtemeljitije uništi, i nastavi s radovima jer su nužni i dobri. (Geiger 189)

Svjestan toga da bi suočavanje s obitelji i njezinom prošlošću eventualno moglo rasvijetliti i neugodne strane njezine prošlosti - njegov otac pripadao je njemačkoj nacionalsocijalističkoj organizaciji mladeži - što bi predstavljalo dodatno opterećenje, odlučuje se za „simbolično brisanje" (Nagy 99) svih tragova obitelji i prošlosti. Velika osobna pogođenost predstavnika prve generacije zbog gubitka sina s jedne strane i aktivno ili pasivno sudioništvo u zločinima s druge strane obilježili su tri generacije te obitelji i doveli je do stanja u kojemu se odbija sjećanje na prošla vremena i prevladavanje obiteljske povijesti. Stariji članovi obitelji nisu govorili o ratnim zbivanjima, ulozi članova obitelji u njima ili vlastitim iskustvima, pa je to znanje ostalo nedostupnim za buduće generacije.

Philipp tako odlučno nastavlja s radovima i čišćenjem. Drži da su svi predmeti nevažni i beskorisni, pa se i sam uključuje u radove: „Philipp s usnama zašiljenim od koncentracije iznosi kartonsku 
kutiju od banana s gomilom papira koje je izvadio iz komoda u bakinoj sobi do kontejnera za stari papir dolje na ulici. Razmišlja da bi za te stvari sigurno bio zainteresiran da su ih umjesto njega bacili susjedi. Ali ovako: ništa od toga." (Geiger 188). Radnici koji provode čišćenje u nekim predmetima prepoznaju vrijednost i od Philippa traže odobrenje da ih uzmu sebi. On im to dozvoljava, ali ipak ne razumije što vide u „bezvrijednim, pokvarenim, suvišnim, beskorisnim” (Geiger 190) stvarima. Radnici ih odlučuju prodati, a dio dobivena novca nude i Philippu, koji ga međutim odbija, jer bi inače prihvaćanjem novca pokazao da je imao barem nekakvu korist od osobnih predmeta članova svoje obitelji. Po završetku radova odlazi iz Austrije i na neki način bježi od ispražnjene kuće i odgovornosti za nju. Premda u suvremenim generacijskim romanima obitelj predstavlja prostor za sjećanje na prošlost, jednako tako jasno oni prikazuju zbog čega se javlja potreba za zaboravljanjem i koje trenutačne posljedice ona ima za obiteljski sustav, ali i dugoročne posljedice za buduće generacije. S obzirom na način ophođenja s obiteljskom prošlošću, kod Geigera je moguće ustanoviti tri različita generacijska tipa: (1) generacija djeda i bake, koja tragične obiteljske sudbine potiskuje kako bi se s osobnim gubitcima lakše nosila, ali u tome ne uspijeva, (2) generacija roditelja, koja ne želi evocirati ni verbalizirati sjećanja jer je sudjelovala u ratu na strani nacionalsocijalista i (3) ravnodušna generacija, koja je svjedok obiteljskih propusta, pa kao posljedica toga ne pokazuje zanimanje za vlastitu obitelji, dok je istovremeno pogođena i opterećena prazninama u pamćenju, tj. neznanjem o obitelji i povijesti i zato jedinim rješenjem smatra potpuno oslobađanje od tog tereta.

\section{Zaključna razmatranja}

U suvremenoj austrijskoj književnosti nakon 2000. godine uočava se trend prikazivanja obitelji i njezine povijesti u društvenim i političkim okolnostima u Austriji prije i poslije Drugoga svjetskog rata i s tim u vezi individualno i kolektivno sjećanje na prošlost. Prikaz sustava obitelji u suvremenim obiteljskim, odnosno generacijskim romanima i u drugim, kraćim proznim djelima, dakle, obuhvaća dvije razine. S jedne strane to su individualne obiteljske priče i sudbine koje se manje ili više odražavaju u identitetu pojedinih članova obitelji, a posebno onih najmlađih. S druge strane, prikazi sudbina austrijskih obitelji neizbježno obuhvaćaju povijesna i društvena zbivanja u Austriji tijekom 20. stoljeća. Pritom se zapaža trijadična generacijska struktura, kojom se upravo i 
uspijeva ostvariti prikaz promjenjivih društvenih prilika i time sudbina obitelji kroz najmanje tri generacije, počevši od djedova i baka, preko očeva i majki pa sve do unuka kao pripovjedača.

Generacijski romani već svojom prezentacijom niza generacija obitelji predočavaju kontinuitet: jedna se generacija rađa, odrasta i osniva vlastitu obitelj, koja potom osniva vlastitu obitelj. Premda se generacije razlikuju po nekim osobnim iskustvima, ipak dijele i neka zajednička iskustva i sjećanja na zajedničku prošlost. Uobičajeno je, a i prirodno da se iskustva i znanja prenose na sljedeće generacije, da se dakle unutar obitelji komunicira o prošlosti i evociraju uspomene. Međutim, noviji austrijski generacijski romani uprizoruju suprotne scenarije i predočavaju propadanje obitelji, što u austrijskoj književnosti ima određenu tradiciju. Kao primjer može se navesti roman Auslöschung. Ein Zerfall (Brisanje. Raspad) Thomasa Bernharda iz 1986. godine koji - kao što se već po naslovu može naslutiti - također tematizira raspad, a riječ je o raspadu jedne austrijske obitelji. Njegov glavni junak, pisac Franz Josef Murau, nakon smrti roditelja i brata vraća se iz Italije u svoju domovinu, gdje bi trebao postati nasljednikom obiteljske imovine. Prisilni povratak u domovinu potiče ga i na suočavanje s obitelji i njezinom prošlošću, ali s namjerom da se pod nju podvuče crta. To mu naposljetku omogućuju njegovo odricanje od naslijeđenoga obiteljskog imanja i konačan odlazak iz Austrije. Slični motivi naziru se i u romanu Es geht uns gut, koji portretira „ravnodušnog mladog pisca kojega prošlost vlastite obitelji ne zanima” (Jabłkowska 302). Propadanje obitelji ovdje uzrokuje potiskivanje prošlosti, kao i opća pasivnost glavnog lika, koju pak on pripisuje svojoj obitelji i njihovoj dominantnoj šutnji. Doznaje se da je upravo djed kao pripadnik i predstavnik prve generacije u tom romanu odgovoran za diskontinuitete u obitelji. $\mathrm{Ne}$ želeći komunicirati o prošlosti, djed uzrokuje i potiče nezadovoljstvo i sukobe između pojedinih generacija, što dovodi do postupnog udaljavanja mlađe generacije i u konačnici do propadanja. To se prvenstveno odražava na drugu generaciju, koja o prošlosti također šuti i raskida veze s ostatkom obitelji. Nastaje duboki „jaz između generacija” (Millner 315) (njem. „Generationenkluft”), tj. između generacije bake i djeda, roditelja i njihove djece, tj. unuka. Tako se u Geigerovu romanu očituje pomak od pisanja o krizi i sukobima unutar dvogeneracijskih obitelji prema pisanju o tro- i više-generacijskim obiteljima.

Arno Geiger svojim je romanom ispisao fragmente povijesti i sudbina jedne austrijske obitelji kroz tri generacije koja se sa svakom novom generacijom sve više raspada, najprije zbog same 
činjenice da živi svjedoci vremena umiru, a onda i zbog ravnodušnosti najmlađe generacije, koja odbija oživljavanje uspomena na njih i suočavanje s prošlošću. Može se, dakle, konstatirati da nijedna generacija ne odgovara na krizu unutar obitelji na način koji bi bio usmjeren na rješavanje iste i da se obitelj kao posljedica izostanka odgovarajuće reakcije na koncu raspada.

\section{Bibliografija}

Assmann, Aleida. „Unbewältigte Erbschaften. Fakten und Fiktionen im zeitgenössischen Familienroman." Generationen: Erfahrung - Erzählung - Identität, uredili Andreas Kraft et al., UVK Verlagsgesellschaft, 2009., str. 49-69.

Dattilio, Frank M., i Arthur Freeman. Kognitivno-behavioralne strategije u kriznim intervencijama. Prevela Mirjana Kirzmanić, Slap, 2011.

Filipović, Vladimir, urednik. Filozofijski rječnik. Nakladni zavod Matice Hrvatske, 1984.

Geiger, Arno. Es geht uns gut. Deutscher Taschenbuch Verlag, 2007.

Gudehus, Christian, Ariane Eichenberg i Harald Welzer, urednici. Gedächtnis und Erinnerung. Ein interdisziplinäres Handbuch. J. B. Metzler Verlag, 2010.

Ivanović, Vesna. „Pojam krize: konceptualni i metodologijski aspekti.” Međunarodne studije, sv. 14, br. 2, 2014., str. 9-29.

Jabłkowska, Joanna. „Kein gewaltiger Schmerz mehr: die geborenen Enkel. Großeltern und Enkelkinder in der österreichischen Literatur um die Jahrtausendwende." Zwischen Aufbegehren und Anpassung. Poetische Figurationen von Generationen und Generationserfahrungen in der österreichischen Literatur, sv. 32, uredila Joanna Drynda, Peter Lang, 2012., str. 293-308. Jurčević Lozančić, Anka. „Redefining the Educational Role of the Family.” Croatian Journal of Education, sv. 13, br. 4, 2011., str. 122-50.

Kešetović, Želimir, i Ivan Toth. Problemi kriznog menadžmenta. Veleučilište Velika Gorica, 2012.

Kiss, Csaba Gy. „Bemerkungen zum Problem des Sogenannten Generationenromans in

Ostmitteleuropa". Neohelicon, sv. 11, br. 1, 1984., str. 161-70.

Kovačec, August, urednik. Hrvatski opći leksikon. Leksikografski zavod Miroslav Krleža, 1996. 
Kriegleder, Wynfrid. „Österreichische Geschichte als Familiengeschichte. Eva Menasses 'Vienna' und Arno Geigers 'Es geht uns gut'." Kindheit. Kindheitsliteratur. Kinderliteratur, Studien zur Geschichte der österreichischen Literatur, uredili Gunda Mairbäurl et al., Praesens Verlag, 2010., str. 225-39.

Landerl, Peter. „Peter Landerl im Interview mit Arno Geiger.” Literaturhaus, http://www.literaturhaus.at/index.php?id=5232. Pristupljeno 28. rujna 2021.

Millner, Alexandra. „Großmama packt aus - Enkelkind schreibt auf. Großeltern, Krieg und Migration in deutschsprachigen Romanen (2000-2010)." Zwischen Aufbegehren und Anpassung. Poetische Figurationen von Generationen und Generationserfahrungen in der österreichischen Literatur, sv. 32, uredila Joanna Drynda, Peter Lang, 2012., str. 309-23.

Moore, Henrietta. „Is There a Crisis in the Family?” Occasional paper (UN Research Institute for Social Development). World Summit for Social Development, no. 3, 1994.

Nagy, Hajnalka. „FamilienGeschichte de/rekonstruiert. Österreichische Familienromane im neuen Jahrtausend." Immer wieder Familie: Familien- und Generationenromane in der neueren Literatur, uredili Hajnalka Nagy et al., Studienverlag, 2012., str. 89-106.

Neuschäfer, Markus. Das bedingte Selbst. Familie, Identität und Geschichte im zeitgenössischen Generationenroman. epubli, 2013.

Prangel, Matthias. „Komplexer als ein Wirtshaus. Ein Interview von Matthias Prangel.”

Literaturkritik, http://www.literaturkritik.de/public/rezension.php?rez_id=10727. Pristupljeno 28. rujna 2021.

Schutti, Carolina, „Erinnerung aus zweiter Hand: Literarisierung medial konservierter Vergangenheiten am Beispiel von Arno Geigers 'Es geht uns gut' und Norbert Gstreins 'Das Handwerk des Tötens'." Verbalisierung und Visualisierung der Erinnerung. Literatur und Medien in Österreich, uredili Anna Byczkiewicz et al., Wydawnictwo Uniwersytetu Łódzkiego, 2008., str. 149-64. 
[1] Uspostavni istraživački projekt UIP-2020-02-3695 Analiza sustava u krizi i nove svijesti u književnosti 21. stoljeća. Projekt financira Hrvatska zaklada za znanost.

\section{(c) $($ (i) (9)}

Creative Commons Attribution-NonCommercial-NoDerivatives 4.0 International License 